УДК 338.5:655.1

\title{
УПРАВЛІННЯ ВИТРАТАМИ НА ПОЛІГРАФІЧНИХ ПІДПРИЄМСТВАХ ІЗ ЗАСТОСУВАННЯМ АЛГОРИТМІВ «ЕКОНОМНОГО ВИРОБНИЦТВА"
}

( Н. І. Передерієнко, к.е.н., доцент, Н. В. Кузьма, студентка, НТУУ «КПІ», Київ, Україна

Проведено исследование различных алгоритмов концепции “экономного производства", проанализированы результаты практического применения алгоритма, адаптированного к отечественным предприятиям в условиях ЗАО «Випол».

Research of different algorithms of conception "economy productions", analyzed the results of practical application of the algorithm, adapted to the domestic enterprises in the conditions of CJSC «Vipol».

\section{Постановка проблеми}

В умовах ринкової економіки серед багатьох проблем поліграфічних підприємств виокремлюється проблема, пов'язана з управлінням витратами, ïх зниженням, найефективнішим використанням всіх виробничих ресурсів. Актуальність даної проблеми зумовлена багатьма чинниками, як забезпечення конкурентоспроможності поліграфічних послуг, прибуткової діяльності та фінансової стабільності суб'єктів господарювання поліграфічної галузі.

\section{Аналіз попередніх досліджень}

Поняття ефективності - економічна категорія, яка виражає результати діяльності підприємства за усіма напрямками його роботи, характеризує співвідношення результатів (доходів) та витрат. Концепція «економного виробництва» заснована саме на ефективному уп- равлінні витратами на всіх рівнях виробництва (матеріальному, фінансовому, управлінському).

МУДА - це японське слово, яке означає втрати, відходи, тобто будь-яку діяльність, що споживає ресурси, але не створює цінності. Система управління, яка забезпечує уникнення безглуздих витрат, отримала назву «економного виробництва». «Економне виробництво» виділяє сім видів МУДА: перевиробництво; запаси (надлишкове надходження продукції в виробничий процес, будь-то сировина, напівфабрикати або готові продукти); надлишкова обробка; зайві рухи (будь-яке переміщення людей, інструменту чи обладнання); дефекти; очікування (перерви в роботі, пов'язані з очікуванням людей, матеріалів); транспортування [1].

Принцип «економного виробництва» зазвичай найчастіше впроваджується на підприємствах, які знаходяться 
в стані занепаду або кризи. Оскільки саме такі компанії більш схильні до швидких та рішучих дій аби не зазнати банкрутства [2].

\section{Мета роботи}

Дослідити і проаналізувати результати практичного використання концепції «економного виробництва» на поліграфічному підприємстві ЗАТ «Віпол».

\section{Результати проведених досліджень}

Ефективність управління витратами було розглянуто на прикладі роботи поліграфічного підприємства ЗАТ «Віпол», де впровадження такого виробництва особливо активно розпочалося після кризи у 2008 р. Серед основних чинників, що зумовили керівництво звернутися до використання МУДА на своєму виробництві були: неефективне використання парку машин та площ, простої обладнання, перерви пов'язані 3 переміщенням, дефекти. Для реалізації запланованих дій знадобилося півтора року, проте варто зазначити, що цей процес триває і дотепер.

Досвід більшості зарубіжних компаній, в тому числі й японських, стверджує, що перетворення варто розпочинати 3 певного підрозділу або цеху, який $є$ найбільш збитковим. На підприємстві «Віпол» цей процес розпочався з друкарського цеху, оскільки прийнято вважати цей цех провідним і в основному вся робота на підприємстві підлаштовується саме під нього. В першу чергу було виявлено непродуктивне устаткування і здійснено його продаж або здача в оренду, що дало можливість компенсувати витрати на його придбання і отримати певний дохід. Також важливе значення надавалося аналізу роботи устаткування, що безпосередньо задіяне у виробничому циклі, зокрема розглядався варіант його заміни на більш сучасне. В результаті, частину обладнання було продано, а на виручені кошти частково оновлено парк устаткуванням фірми Heidelberg. Таким чином парк було реорганізовано і тепер його склад складає приблизно 10 робочих машин. Цей захід дав змогу скоротити витрати на утримання устаткування, його ремонт, покращити якість продукції. Серед показників що характеризують ефективність проведеної політики можна виділи коефіцієнт використання обладнання який зріс від 60 \% до 100 \%,та скорочення часу наладки на $25 \%$.

Серед інших заходів проведених на виробництві було скорочення непродуктивних площ, в тому числі і складських. Проблема, яка виникає в процесі запровадження «економного виробництва» на даному етапі налагодження роботи з постачальниками та дистриб'юторами. Цей процес $є$ дуже важливим, оскільки навіть за умови доскональної роботи всередині підприємства, несвоєчасні поставки матеріалів можуть дезорганізувати увесь процес i збільшити, а й навіть зірвати строки виконання замовлення. Тому на більшості поліграфічних підприємствах практикують створення достатньо великих обсягів запасів, які в свою чергу 
збільшують площі і витрати на їх утримання. Замовників же цікавить лише продукція, зроблена якісно і виконана вчасно. Оскільки «Віпол» вже давно працює на ринку (з 1974 р.) він має свою базу постачальників, відносини з якими налагоджено на вигідних для обох сторін умовах. Домовившись про більш часті поставки матеріалів меншими партіями, підприємству вдалось уникнути великих запасів і в свою чергу скоротити площі до мінімально необхідних. Решту приміщень, в тому числі, і невиробничого призначення було надано в оренду іншим приватним особам та підприємствам. Таке скорочення, приблизно на $34 \%$ збільшило показник корисного використання складських площ на $23 \%$.

Не менш важлива діяльність була проведена в організаційному процесі: перехід підприємства на скорочений тиждень, дозволив зберегти чисельність працівників майже в повному складі; організаційноструктурна побудова підприємства покращилась - процеси прийняття і виконання рішень проводилися з врахуванням рекомендацій нижчого керівництва, кількість функцій і відділів також дещо скоротилася.

Досягнення певних результатів на проблемних ділянках означає, що компанія рухається у вірному напрямку, і це подальший крок до змін на інших дільницях та цехах.

Сутність «економного виробництва» можна сформулювати за допомогою певних принципів:
- Основна ціль - гнучкість виробництва.

- Готовність до змін ритму виробництва.

- Рухливість робочої сили суміжність професій.

- Профілактика обслуговування обладнання.

- U-образні або паралельні потокові лінії.

- Близьке розташування робочих місць і ліквідація конвеєрів.

- Закупівля невеликих станків (машин), збільшення їх кількості по мірі необхідності, а не купівля дорогих «супермашин» 3 намаганням забезпечити їх повну завантаженість.

Один із основних принципів «економного виробництва» заключається у створені потоку, безперервному виготовлені продукції, уникаючи витрат часу переміщення між дільницями, простоїв і т. д. [3]. Адаптуючи вищевказане до роботи поліграфічного підприємства, варто зазначити, що тут гнучкість виробництва у післядрукарському цеху забезпечили невеликими поліграфічними станками, а не купівлею затратної потокової лінії. Потоковість - синхронність або рівність по часу операцій на процесах виробництва здійснили за допомогою U-образного розташування поліграфічних машин. Практика показує, що це дозволяє не лише зменшити непродуктивні площі, позбутися витрат часу на транспортування, позбутися непродуктивних (малопродуктивних) дільниць, простоїв; а й контролювати увесь процес виробництва, своєчасно реагувати на брак чи зупинки у випадках технічних проблем [4]. 
Також не менш важливим пунктом у системі «економного виробництва» $€$ якість продукції. На цьому шляху важливою $€$ ліквідація браку на його початкових етапах. Оскільки, в подальшому при ігноруванні дефектів переробка продукції обійдеться в декілька разів дорожче. До впровадження на підприємстві нових методів управління витратами одним із незадовільних показників були втрати від браку та терміни ї усунення. 3 проведенням заходів щодо професійної підготовки та виділенням коштів на підвищення кваліфікації майже чверті промислово-виробничого персоналу, показники продуктивності значно зросли, а кількість браку та відходів, пов'язаних із ним, скоротилася; підвищилась універсалізація працівників. Прийнято виділяти декілька алгоритмів введення «економного виробництва»:

- За Дж. Вумеком

1. Виділити виконавців втілення концепції (залучити 3 інших підприємств), забезпечити його інформацією.

2. Виділити проблемні зони або створити кризу в компанії.

3. Розпочати усунення кризових ділянок зі стратегічним плануванням.

4. Намагатися негайно отримати результат.

5. Створювати неперервні покращення за системою Кайдзен [1].

\section{- За Деннісом Хоббсом}

1. Запустити проект (сформулювати ціль і показники. Створити склад команд і навчити учасників. Скласти план дій).
2. Задокументувати усі виробничі процеси і продукцію (виявити продуктивність процесів 3 розрахунком варіативності, повторної обробки і відходів).

3. Закінчити збір інформації і затвердити дані для створення економної лінії.

4. Створити макет економної лінії.

5. Розпочати роботу на економній лінії (перевірити збалансованість лінії, засвідчити у правильності розподілу завдань, розробити план поступового скорочення запасів незавершеного виробництва).

6. Розробка кроків для подальшого удосконалення (перевірити роботу лінії і розробити стратегію корекції) [5].

- За Хаммером (5S)

1. Сортування - визначити всі матеріали, ресурси, обладнання за принципами (потрібні завжди, інколи, брак).

2. Дотримання порядку: безпеки, якості, ефективності роботи.

3. Дотримання чистоти.

4. Стандартизація - письмове закріплення правил утримання робочого місця, технології роботи та інших процедур. Створення робочих інструкцій.

5. Вдосконалення спостереження за роботою обладнання; використання фотографії до/після; організація аудиту [6].

- Кайдзен

1. Створити команду та визначити пріоритетні напрями роботи, використовуючи діаграму Парето.

2. Визначити причини виникнення проблеми та кризові ділянки. Використовують діаг- 
рами Ісікави, причинно-наслідковий зв'язок.

3. Вибрати найкращі рішення проблем за затратами, ефективності та ризикованості проекту.

4. Провести експеримент по впровадженню на виробництві.

5. У випадку його успішного проведення з отриманням позитивних результатів - реалізувати спочатку на проблемних зонах, а потім поширити на усе виробництво.

6. Прослідити вплив на проблемних ділянках. Вдосконалити процеси на ділянках з найменшим корисним ефектом [1].

Аналізуючи впровадження того чи іншого алгоритму на прикладах підприємств, де вони мали безпосереднє використання, варто зазначити, що всі вони мали свій успіх. У ЗАТ «Віпол» впровадження швидше за все здійснювалося за алгоритмом Кайдзена.

Хоча варто відмітити тенденцію: більшість 3 компаній не зупиняються на використанні одного алгоритму, а використовували їх у комплексі (оскільки вони є досить схожими, за певними відмінностями) або впроваджуючи їх один за одним. I така кооперація має свої результати - після впровадження системи «економного виробництва» усі компанії змогли вийти з кризи і стати лідерами в своїй галузі, зокрема, аналізоване підприємство знаходячись лише на початку шляху вже змогло досягнути певних результатів і головним із них $€$ те, що воно продовжує своє функціонування отримуючи при цьому прибуток.

\section{Висновки}

Таким чином, проведене дослідження виявляє закономірність між впровадженням на підприємстві моделі управління витратами та підвищенням ефективності його діяльності, що $є$ актуальним в умовах ринкового механізму та конкурентоспроможності. Теорія «економного виробництва» припускає можливість мінімізації витрат і реалізацію досягнення ефекту максимізації прибутку за умови дотримання чіткого плану дій на усіх рівнях та етапах.

1. Вумек Дж. Бережливое производство. Как избавиться от потерь и добиться процветания вашей компании / Дж. Вумек, Д. Джонс. - 2-е изд. М. : Альпина Бизнес Букс, 2005. - 473 с. 2. Шонбергер Р. Японские методы управления производством. Девять простых уроков : сокр. пер. с англ. / Науч. ред. и автор предисл. Л. А. Конорева. - М. : Экономика, 1988. 251 с. 3. Мерзликина Е. М. Методология оценки эффективности деятельности организации (на примере отрасли печати) / Е. М. Мерзликина. - Автореферат дис. д.э.н. - М. : МГУП, 2008. - 334 с. 4. Павлова Г. В. Управление производительностью полиграфического предприятия / Г.В.Павлова, В. К. Кондрашова : Монография. - М. : МГУП, 2006. - 104 с. 5. Хоббс Д. П. Внедрение бережливого производства : практическое руководство по оптимизации бизнеса / Д. П. Хоббс. - Минск : Гревцов Паблишер, 2007. 352 c. 6 . $5 \mathrm{~S}$ for Operators : 5 Pillars of the Visual Workplace [Електронний ресурс]. - Спосіб доступу : http://www.epa.gov. 
1. Vumek Dzh. Berezhlivoe proizvodstvo. Kak izbavit'sja ot poter' i dobit'sja procvetanija vashej kompanii / Dzh. Vumek, D. Dzhons. - 2-e izd. - M. : Al'pina Biznes Buks, 2005. - 473 s. 2. Shonberger R. Japonskie metody upravlenija proizvodstvom. Devjat' prostyh urokov : sokr. per. s angl. / Nauch. red. i avtor predisl. L. A. Konoreva. - M. : Jekonomika,1988. - 251 s. 3. Merzlikina E. M. Metodologija ocenki jeffektivnosti dejatel'nosti organizacii (na primere otrasli pechati) / E. M. Merzlikina. - Avtoreferat dis. d.je.n. - M. : MGUP, 2008. 334 s. 4. Pavlova G. V. Upravlenie proizvoditel'nost'ju poligraficheskogo predprijatija / G. V. Pavlova, V. K. Kondrashova : Monografija. - M. : MGUP, 2006. 104 s. 5. Hobbs D. P. Vnedrenie berezhlivogo proizvodstva : prakticheskoe rukovodstvo po optimizacii biznesa / D. P. Hobbs. - Minsk : Grevcov Pablisher, 2007. - 352 s. 6. 5S for Operators : 5 Pillars of the Visual Workplace [Elektronnyi resurs]. - Sposib dostupu : http://www.epa.gov.

Рецензент - А. В. Кваско, к.е.н., доцент, НТУУ «КП|»

Надійшла до редакції 23.12.12 